\title{
Evaluating the EU as a Global Leader in International Development
}

\author{
SARETH KAILAS KUMARESAN \\ University of Canterbury, New Zealand \\ sarethkailas@yahoo.com
}

\begin{abstract}
As the second-largest economy in the world and as the largest provider of development assistance, the $E U$ is a major actor and agenda-setter in international development. This paper seeks to examine the tools used by the EU in providing assistance and the ways in which its approach to development are different to those adopted by other major actors. The EU's use of ODA and market access are distinguished as two major tools employed by the Union to promote its vision for development. Major challenges to the EU's pre-eminence in the field are also outlined, particularly focusing on challenges arising from the emergence of the Chinese model of development assistance. Drawing on reports produced by the European Commission and academic studies, therefore, this paper finds that while there are inherent shortfalls in its approach, with strong normative underpinnings and a long-term oriented approach, the EU remains a successful and prominent actor in international development.
\end{abstract}

Keywords: European Union, Development, ODA, Trade, Afghanistan, China

\section{Introduction}

Historically, development as a concept has denoted that countries have varying levels of "development" based on their economic status, giving rise to a binary notion that there are developed and developing nations in the world. In the $21^{\text {st }}$ century, development as a policy area has evolved from a purely economic outlook towards emphasising a comprehensive socio-political and economic process through which developing nations can achieve sustainable growth (Gänzle et al., 2012, p.2). The European Union (EU), as an economic superpower with historic colonial links to the developing world thus, has a significant role in global development discourse. Since the Maastricht Treaty of 1992, development policy has been an EU community competence and is based on the principles of promoting sustainable development, eradicating poverty, and integrating developing nations into the global economy (Mold, 2007, p.47). Therefore, with a strong commitment to translating these principles into practical and effective projects, the EU has become an agenda-setter in global development and employs various methods to assist developing nations. In particular, the economic power of the Union has allowed it to become the largest aid donor in the world, a role which it has utilised to foster comprehensive and tailored developmental activities, as evidenced by the EU's involvement in Afghanistan. Preferential market access and trade relations have also been used to level the playing 
field and serve as an incentive for developing nations to accept EU conditionalities that promote changes for sustainable economic and socio-political development. However, the EU's approach does have inherent shortfalls and faces challenges from new actors such as China, who take a less intrusive approach in providing development assistance. Thus, while there are shortcomings in its approach, guided by normative and practical policies, the EU still stands as a credible and successful actor leading the field of development (Davies, \& Nilsson, 2020, p.2).

\section{EU Official Development Assistance and the Example of Afghanistan}

One advantage the EU has over other actors, stemming from its position as the largest Official Development Assistance (ODA) donor in the world, is its ability to use the "power of the purse" (Gänzle et al., 2012, p.23) to influence the global development agenda. The first Lomé Convention established the foundation of the EU's role as an international donor by creating ODA funding organs such as the European Development Fund (EDF) (Mold, 2007, p.41). While agencies for distributing ODA are a global staple, the EU's focus on using these funds to achieve the aims set out in the Maastricht treaty and the more recent European Consensus on Development (2017), based on the UN's Sustainable Development Goals (SDGs), are not universal. In some regards, therefore, the EU's development outlook is more progressive, with the EU championing projects which are comparatively altruistic, a prime example of which is the slow phasing out of tied aid. Thus, while other actors like the US still provide up to $50 \%$ of their food aid with tied conditions that benefit US producers, as of January 2020, over 92\% of the EU's ODA was untied, allowing recipient nations to tailor aid funding to their needs (Holden, 2009;2016, p.126-130). The ability to tailor aid is another EU strength, as it ensures that ODA funding meets the needs of the local population and builds the capacity of recipient nations to take charge of the development process in the long run. The EU thus funds tools such as the Instrument for Stability (IfS) through the European External Action Service to create the necessary conditions for development activities to be effective (Gänzle et al., 2012, p.131-133). The IfS is designed to react to pressing global crises that threaten stability and the rule of law before they deteriorate further, allowing the EU to establish peace and stability without the need for military intervention (Biscop, 2005;2016, p.25). Through funding programs such as these, the EU establishes "meaningful engagements" (Biscop, 2005;2016, p.67) with developing nations, ensuring that its ODA has a lasting impact not just on economic growth but also on socio-political conditions. Moreover, EU ODA is not only donor oriented but also strongly committed to multilateral cooperation in order to ensure maximum effectiveness and cohesion of aid policies and projects. With international development being an incredibly clustered space, the EU's internal efforts in achieving policy cohesion, as well as its sustained commitment to working with other national, multilateral, and non-governmental organisations, have ensured that redundant and overlapping aid activities have diminished (Gänzle et al., 2012, p.239). Ultimately, therefore, the EU's willingness to adopt and implement cosmopolitan ideals through its ODA gives the Union greater credibility as a genuinely altruistic actor (Del Biondo et al., 2008, p.121).

An example that showcases the impact and effectiveness of EU ODA is the case of Afghanistan. With a myriad of socio-economic issues and defined by the United Nations as a Least Developed Country (LDC), the EU has had a significant role in the development of Afghanistan in the $21^{\text {st }}$ century. As the largest recipient of EU ODA, 
with 1.4 billion Euros invested in the country between 2014 and 2020, the EU views development in the region as a strategic means to tackle radicalism and foster greater regional and global stability (European Commission, 2019). The EU has thus funded activities that work to establish peace, democracy, and essential social services as a means to ensure that development is sustainable and controlled by the people of the country (Biscop, 2005;2016, p.25). Therefore, while the EU's activities in Afghanistan are numerous, its nature and impact can be exemplified by efforts in the health and governance fields. For example, EU funding for the Law and Order Trust Fund effectively supports the payroll of 124,000 employees of the Ministry of Interior in charge of maintaining the rule of law in the country. Its activities in health have also resulted in 296 new health facilities which serve the most remote and overlooked regions, helping to combat malnutrition and mortality rates in the country (European Commission, 2019). Hence, EU ODA stands apart from traditional military and infrastructure funding often provided to Afghanistan and instead focuses on grassroots activities aimed at achieving stability and sustainable development. Thus, as showcased by its efforts in Afghanistan, while many nations are active donors, the EU's commitment to progressive principles and efforts to make ODA truly recipientoriented make it a leader amongst global developmental actors.

\section{The Trade-Development Nexus}

While the EU's role as the biggest global aid donor can be viewed as active external involvement, the trade-development nexus, established as one of the EU's development policy cornerstones, is a more passive means through which the EU helps developing nations. The EU has used trade as a development tool since the Treaty of Rome in 1958, which, at the time, sought to provide preferential market access to African, Caribbean and Pacific (ACP) states, most of which were former European colonies. Now, with considerably more trading power, the EU uses market access and a scheme of trade preferences under the Generalised System of Preferences (GSP) as an incentive for developing nations to liberalise economically and foster growth (Del Biondo et al., 2008, p.111-114). While almost all developed economies use GSP as a trade tool, the EU's application of the concept is uniquely stratified into a pyramid of trade preferences with four distinct stages. Developed nations are at the bottom and receive little to no benefits. In the second stage, the standard GSP scheme is applied to lowermiddle and middle-income nations, entailing partial exemption of customs duties and alleviation of $2 / 3$ of the tariffs. The next stage, the GSP+ category, removes all tariffs and duties and is intended to benefit low-income and vulnerable nations. The final stage of the EU preference system is reserved for LDCs who have access to the Everything But Arms (EBA) initiative. The EBA benefits the LDCs as all their goods and services gain quota, tariff and duty-free access to the European market. The stratified preference system not only allows the EU to tailor assistance according to a nation's level of development but also makes it easier to apply specific conditionalities to foster more comprehensive development in the most vulnerable nations (Del Biondo et al., 2008, p.113-115). Therefore, the GSP+ and EBA schemes require that nations sign 27 major international conventions (Del Biondo et al., 2008, p.125), ranging from adherence to good governance standards to compliance with the Paris Agreement (European Commission, 2020a, p.2).

Furthermore, the uniqueness of its GSP model also means that engaging with the EU has specific benefits not found with other developed nations. One major strength of the EU's GSP programme is its flexibility, which is in stark contrast to the GSP programme 
of the US. The American system, which does not have as many stratified levels, imposes relatively strict conditions for all developing nations (Jones et al., 2011, p.2-3). For example, the lack of differentiation in the US's application of GSP means that lowincome nations such as Pakistan, which produce similar products to those of India, a much larger economy, would have to compete on the same level. In contrast, in the EU system, India falls under the standard GSP scheme with fewer benefits, while Pakistan gets more preference under the GSP+ scheme, levelling the playing field (Jones et al., 2011, p.2). Another advantage of trading with the EU under the preferential trade system is that industries in the developing nations strengthen over time to become competitive in a free market. This is because the GSP conditionalities of the EU bring production, manufacturing, and labour standards in developing nations to International levels. The EU's market power also means greater job creation and technical assistance for developing nations, all of which, as put forth by Jones et al. (2011), acts as a means of "apprenticeship and benchmarking" (p.8). These positive impacts are evident in the case of Sri Lanka, where since the turn of the Century, GSP+ conditionalities have reduced child labour numbers from 16\% to 1\% (European Commission, 2020a, p.2-8). Bangladesh has also benefited under the EBA category, with the favourable access to the European market helping create an estimated 5 million jobs between 2018-2019 (European Commission, 2020a, p.2-8).

The EU also uses its trade policy to help resource-dependent nations, especially those that are over-dependent on agriculture, forestry and mineral extraction for economic growth as they are vulnerable to market fluctuations. This form of assistance entails the free transfer of technology and technical assistance to enable developing nations to adapt and diversify their economies and societies (European Commission, 2011, p.511). This comprehensive commitment is exemplified by the European Union's Energy Initiative (EUEI), the EU's framework to ensure that developing nations have the necessary skills and means to independently control the development agenda (European Commission, 2011, p.25). One of the most successful policies implemented under the EUEI was the Timber Regulation rules adopted by the EU in 2013. The regulations required producers in developing nations to enact a "due diligence" system to ensure that timber brought to the European market is not harvested illegally or unsustainably. This policy substantially reduced illegal timber imports by more than 25\% (European Commission, 2011, p.28-31). Ultimately, therefore, EU conditionalities aim to lay the groundwork for successful long-term development by incentivising developing nations to undertake socio-economic reforms in return for preferential market access.

\section{Shortfalls in the EU's Approach to Development and the Challenges Posed by the Chinese Model}

While the EU is a preeminent actor in development, it does face systemic challenges over the distribution and implementation of its aid, and questions still remain over the actual impact created by its projects. The main criticism is that despite offering flexible policies and need-based allocation of ODA, less than 10\% of the EU funding reaches the LDCs where it is needed most (Barbagallo et al., 2019, p.19-20), with 16 of the poorest nations receiving only $8 \%$ of EU funding (Barbagallo et al., 2019, p.5). Moreover, as a sizeable supranational entity, the EU has an extensive bureaucratic system, making the process of receiving aid infamously slow. This fact is backed up by figures from 2007 to 2013 , during which period only $30 \%$ of the contracted aid had been paid (Bossuyt, 2018, p.12). Therefore, the slow process and inherently long-term 
nature of EU aid projects have raised questions over the efficacy of EU ODA in the short-term, especially considering EU assistance is often accompanied by expensive and substantial conditionalities. Questions over the normative underpinnings of EU ODA have also been further exasperated by the perceived selective application of conditionalities on weaker states dependent on aid. This is because, due to geopolitical considerations, larger nations such as Indonesia receive the benefits of EU funding and preferential market access without facing the same level of EU interference in political and economic policy (Mold, 2007, p.248). This leads to a significant challenge facing the EU in global development, which has been the rise of new powers such as China, which have ramped up development activities following a different approach to development.

The friction between the policies of the EU and China are in direct conflict in Central Asia, where local governments, most of which are authoritarian or oligarchic, find Chinese aid more attractive due to the lack of conditionalities (Bossuyt, 2018, p.14). Moreover, while the EU fundamentally tries to achieve development through stable, inclusive and sustainable methods, China focuses on rapid economic growth through infrastructure investment. China thus helps developing nations less through ODA and more through concessional loans and state subsidised investments in infrastructure and natural resource extraction (Bossuyt, 2018, p.2-9). Compared to the EU, therefore, Chinese assistance is more prevalent and preferred in Central Asia, especially since immediate results are guaranteed. This was evidenced when Chinese President Xi Jinping offered a loan and investment package of 10 billion dollars to Kazakhstan and 48 billion dollars for the entire region in 2013. In contrast, the EU's focus is limited to the poorest nations in the region, such as Kyrgyzstan and Tajikistan, who are willing to meet the EU's conditionalities (Bossuyt, 2018, p.6-9). However, while China does challenge the EU model for development by funding flashy projects and promising immediate results, it does not help developing nations build capacity in the long run. This lack of focus on sustainable forms of development is a weakness in the Chinese development policy, as without good governance and other prerequisites fostered by EU conditionalities, the long term prospects for developing nations would be negative (Bossuyt, 2018, p.15). Furthermore, in discussing the shortfalls of the EU's approach, it is also worth noting that the EU as an aid actor is still constrained by internal politics of member states and geopolitical factors which influence the development policies of the Union. Thus, while LDCs are somewhat neglected by the EU approach and questions remain over the immediate results of EU ODA, there have been recent commitments to refining the process. (European Commission, 2020b). In particular, the commitment in 2017 to the Policy Coherence for Development (PCD) seeks to refocus and streamline EU projects towards result-oriented and effective development activities. The adoption of the PCD is, therefore, indicative of the EU's commitment to refine its methods, which will ensure that the EU remains a relevant actor in the development field (European Commission, 2020b).

\section{Conclusion}

In conclusion, therefore, the EU's considerable economic power, combined with its comprehensive approach to development, make it an effective global actor in the field of development. The "power of the purse" allows the EU to positively influence the global development agenda, particularly by championing progressive policies and setting an example for other donor nations to follow. This has been witnessed in Afghanistan, where the EU's comprehensive approach has been markedly different in 
its focus on grassroots programmes that improve socio-economic conditions and foster sustainable growth for the long run. Moreover, its ability to use trade and market access as incentives are other highly effective tools at the EU's disposal, which have been employed to help developing nations strengthen their economies by offering preferential access. Through conditionalities that accompany trade incentives, the EU has also been able to bring standards relating to labour and environment to international standards, thereby building capacity and integrating developing states into the global economy. Finally, while new and less intrusive approaches to development have emerged from emerging powers such as China, the grassroots and sustainable approach to helping developing nations espoused by the EU is unparalleled in the global context. Thus, comparatively, the EU stands out as a progressive and altruistic actor leading international development activities and discourse.

\section{References}

Barbagallo, V., Oliveira, A., \& Pereira, J. (2019). Leaving No One Behind: Time for Implementation. Concord - European NGO Confederation for Relief and Development. https://concordeurope.org/wpcontent/uploads/2019/11/CONCORD AidWatch Report 2019 web.pdf

Biscop, S. (2005;2016). The European Security Strategy: A Global Agenda for Positive Power. Ashgate. https://doi.org/10.4324/9781315239835

Bossuyt, F. (2018). The EU's and China's Development Assistance Towards Central Asia: Low Versus Contested Impact. Eurasian Geography and Economics, 59(5-6), 606631. https://doi.org/10.1080/15387216.2019.1581635

Davies, E., \& Nilsson, L. (2020). A Comparative Analysis of EU and US Trade Policies Towards Least Developed Countries and the African Growth and Opportunity Act Beneficiaries. Development Policy Review, 38(5), 613629. https://doi.org/10.1111/dpr.12434

Del Biondo, K., De Ville, F., Drieghe, L., \& Orbie, J. (2008). Changing Trade Relations Between the European Union and the Developing World: On Pyramids and Spaghetti Bowls. Studia Diplomatica, 61(2), 111-131. www.jstor.org/stable/44839027

European Commission. (2011). Supporting a Climate for Change: The EU and Developing Countries Working Together [EU Commission - Brochure]. The European Union. http://aei.pitt.edu/46109/1/climate 2011.pdf

European Commission. (2019). International Partnerships: Afghanistan. The European Union. https://ec.europa.eu/international-partnerships/where-wework/afghanistan en

European Commission. (2020a). Report on the Generalised Scheme of Preferences Covering the Period 2018-2019 [Joint Report To the European Parliament and the Council]. The European Union. https://trade.ec.europa.eu/doclib/docs/2018/january/tradoc_156536.pdf

European Commission. (2020b). Policy Coherence for Development. The European Union. https://ec.europa.eu/international-partnerships/policy-coherence-development_en

Gänzle, S., Grimm, S., \& Makhan, D. (2012). The European Union and Global Development: Enlightened Superpower in the Making?. Palgrave Macmillan. 
Holden, P. (2009;2016;). In search of structural power: EU aid policy as a global political instrument. Ashgate. https://doi.org/10.4324/9781315588148

Jones, V., Hornbeck J.F., Villarreal M.A. (2011). Trade Preferences: Economic Issues and Policy Options [Report No. R41429]. Congressional Research Service 1-34. https://www.google.co.nz/books/edition/Trade_Preferences_Economic_Issues_and Po/OLg02Zk5N-IC?hl=en\&gbpv=1\&printsec $=$ frontcover

Mold, A. (2007). EU development policy in a changing world: Challenges for the 21st century. Amsterdam University Press. ProQuest Ebook Central https://ebookcentral.proquest.com/ 